\title{
Reverential abandonment: a termination ritual at the ancient Maya polity of El Palmar
}

Kenichiro Tsukamoto*

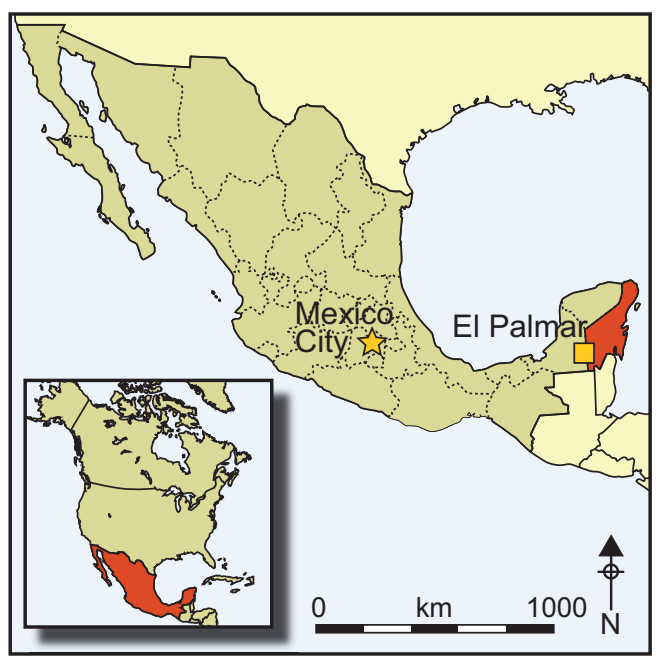

Archaeological evidence for Maya termination rituals has been reported from several sites, but spatial analyses based on quantitative data have not previously been undertaken. This study uses spatial analysis of deposits at the Guzmán Group, an outlying architectural group within the Maya centre of El Palmar in Mexico, to identify the participants and their behaviour in the termination ritual, along with associated public activities. Results suggest that participants were Guzmán Group inhabitants, who intentionally placed particular items in specific locations. The size and usewear of vessels suggest repeated feasting events in the plaza. The study highlights the significance of contextual analyses for a greater understanding of the spatial dynamics inherent in the abandonment processes of early complex societies.

Keywords: Mesoamerica, El Palmar, Maya, abandonment processes, feasting, termination ritual

\section{Introduction}

The study of abandonment processes through archaeological remains is challenging. Among the wide array of ancient Maya rituals, closure or termination rituals have made it especially difficult for researchers to reconstruct those processes. Although some archaeologists still claim that termination deposits are refuse dumps ascribed to post-abandonment squatters, theoretical and methodological advances in Maya archaeology have recently enabled us to distinguish termination deposits from domestic middens (Freidel 1986; Inomata 2003; Stanton et al. 2008). Case studies from the last two decades have demonstrated that

* Department of Anthropology, University of California, Riverside, 1334 Watkins Hall, Riverside, CA 925210418,USA (Email: kenichiro.tsukamoto@ucr.edu) 


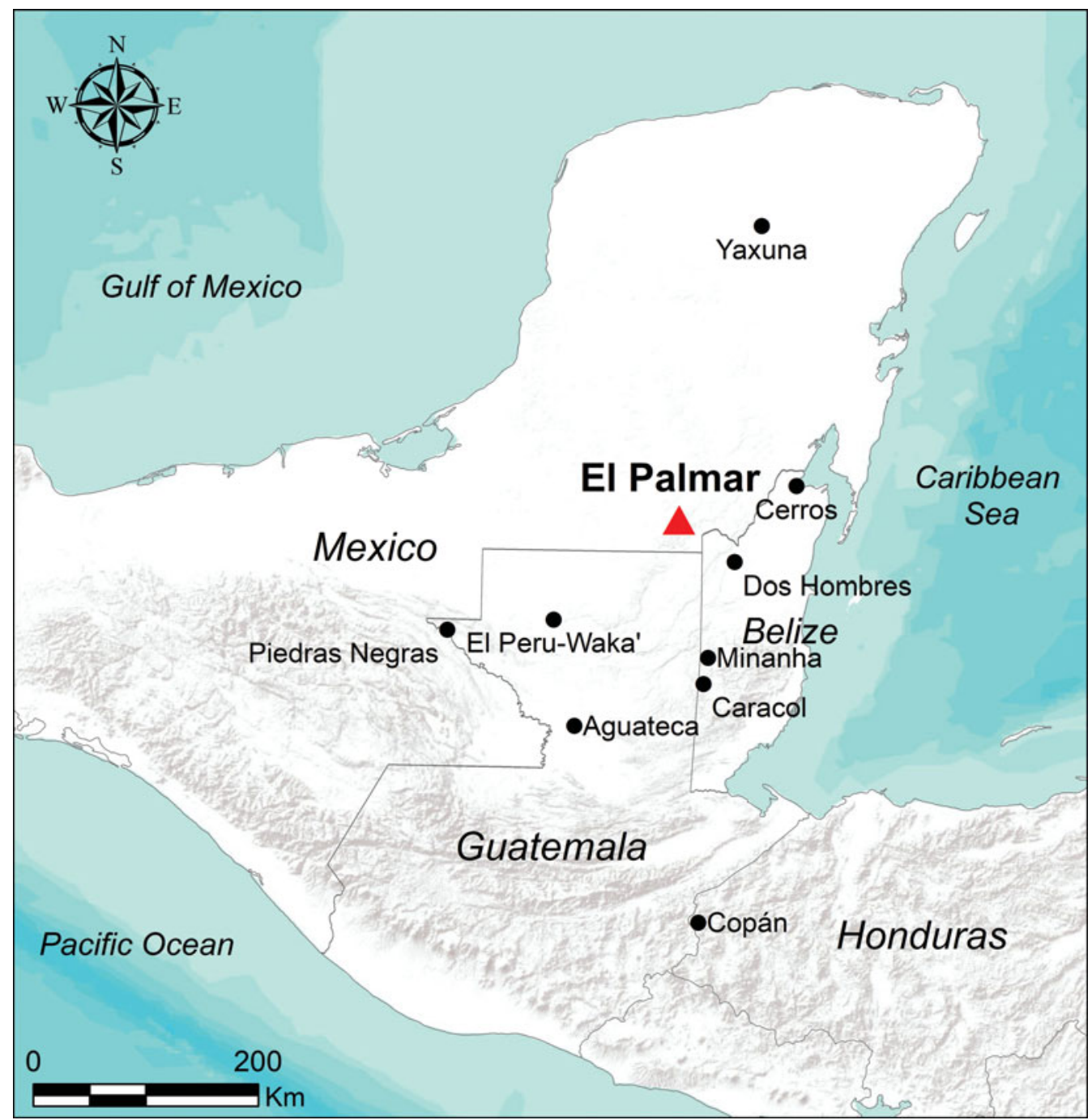

Figure 1. Map of ancient Maya centres where termination rituals have been reported.

termination rituals varied in different historical and regional circumstances (e.g. Mock 1998; Pagliaro et al. 2003). Nevertheless, differentiating abandonment processes is not easy, as they leave similar evidence in the material remains (D.S. Walker 1998: 85).

This study is an attempt to discern the variability inherent in termination rituals. Although termination rituals were also dedicated to the renewal of structures and objects, they will be examined here in an abandonment context. It will be demonstrated that rigorous spatial analyses based on quantitative data enable us to identify these often indiscernible ritual behaviours. The emphasis is then on a termination ritual that took place at the Guzmán Group, an outlying architectural group within the territory of the major polity of El Palmar in the Maya lowlands (Figure 1). Events resembling termination rituals have also been reported in other parts of the New World, including Mesoamerica, 
the Andes and the American Southwest (Grove 1984; W.H. Walker 1998; LaMotta \& Schiffer 1999; Manzanilla 2003; Matsumoto 2012; Velásquez 2015). Hence close scrutiny of termination rituals in the Maya area can provide insight into the nature of abandonment processes in the New World, and will establish a robust basis for future comparative studies with those of the Old World.

\section{Termination rituals in ancient Maya society}

Mesoamerican archaeological research has long reported termination rituals in which artefacts and architectural elements were ritually 'killed' (e.g. Coe 1959; Grove 1984; Freidel \& Schele 1989; Mock 1998; Sugiyama 1998; Sullivan et al. 2008). In termination rituals, participants defaced, mutilated, dismantled or altered portable objects, human and faunal bones, monuments and buildings (Freidel 1986). Termination deposits are often recovered together with charcoal concentrations, indicating that artefacts were placed on floors and then probably burned. Although archaeologists studying the Maya had previously reported termination deposits (e.g. Coe 1959), Freidel and colleagues were the first to consider termination rituals as a focal point in Maya archaeology (Robertson \& Freidel 1986; Garber 1989). During fieldwork at the centre of Cerros in Belize, they discovered structures whose plaster façades had been dismantled. Around these structures, they found numerous smashed artefacts intermixed with white marl.

The large quantity of material deposits associated with structures at Maya centres has provoked persuasive, evidence-driven debates amongst scholars as to whether the deposits represent domestic refuse or the remains of termination rituals. To address this problem, Stanton and colleagues (2008) extensively reviewed archaeological, ethnohistoric and ethnoarchaeological sources that describe midden-like deposits across Maya communities. Their reviews suggest that the ancient Maya did not use abandoned structures as refuse dumps, and that domestic floors tended to be devoid of refuse. The ethnoarchaeological and archaeological studies have yielded different patterns inherent in refuse disposal (Hutson et al. 2007). Middens were usually placed near the edge of patios or in non-activity areas. Termination deposits could, therefore, be identifiable in archaeological research.

Although termination rituals usually entail acts of destruction, they are not always tied to such behaviours. At Copán, in Honduras, Agurcia and Fash (2005: 209) reported that unbroken artefacts had been placed on the backbench of the central room, located in a substructure of structure 10L-16 (known as Rosalila). Spectacular termination deposits at Rosalila included eccentric flints, chert knives, carved jade, stingray spines, spiny oyster shells, baby shark vertebrae, jaguar claws and several incense burners. Unlike at other centres, the inhabitants of Copán did not dismantle the substructure's modelled stucco reliefs, but instead carefully covered them with a thick coat of white stucco, followed by a fill of stones and mud. Copán, therefore, exhibits the variability inherent in termination rituals.

With the increasing recognition of archaeological termination rituals, scholarly concern has shifted to its range of variation. Pagliaro and colleagues (2003) classify two types of termination rituals. Desecratory termination rituals stem from violent conflicts, such as warfare and internal friction, whereas reverential termination rituals are not associated with (C) Antiquity Publications Ltd, 2017 
such conflicts (Lamoureux-St-Hilaire et al. 2015: 553). A key difference between the two types of termination rituals lies in who conducted them. Ethnohistorical and ethnographic studies show that the agents of reverential rituals are owners and/or affiliates who have been directly associated with that material culture (Tozzer 1941; Stross 1998). They conduct termination rituals when the role of an artefact, structure or site ceases. In contrast, studies suggest that desecratory termination rituals were performed by enemies or other internal antagonistic factions, who sought to destroy the supernatural powers attached to rival communities, and to humiliate the owners who lived in structures or sites that were targeted (e.g. Inomata 2003).

The conceptual differentiation between these two types of termination rituals is relatively clear, but their identification in the archaeological record is problematic. If reverential termination rituals left material traces, as at Copán, then identification should be straightforward. Reverential termination rituals or other dedicatory rituals, however, often entail destructive behaviour (Stross 1998; D.S. Walker 1998). As they leave similar evidence in the material record, a qualitative analysis would not suffice. Quantitative analysis is necessary for a better understanding of termination rituals (Stanton et al. 2008: 228). Furthermore, it is argued here that the spatial analysis of termination deposits illuminates the abandonment process of ancient Maya society. The present study, therefore, combines spatial analyses with quantitative data to identify details of termination rituals. Excavations at the Guzmán Group yielded rich data that are indispensable for applying distinctive approaches for understanding termination rituals in abandonment processes.

\section{The Guzmán Group at El Palmar}

El Palmar is located in south-east Campeche, Mexico. The ancient Maya initially constructed gathering spaces at the civic core, or the Main Group, during the Late Preclassic period (c. 300 BC-AD 250), and it became a major polity after the Middle Classic period (c. AD 400-600). Since 2007, the author has codirected the El Palmar Archaeological Project with Javier López Camacho. Surface survey has so far recorded eight outlying architectural groups in addition to the Main Group. The Guzmán Group is one of these outlying groups, located $1.3 \mathrm{~km}$ north of the Main Group (Figure 2). It is a small architectural group, with a $3 \mathrm{~m}$-high temple and lower rectangular structures that form a plaza.

The hieroglyphic inscriptions carved on a small temple stairway (structure GZ1) suggest that, despite its modest dimensions, the Guzmán Group must have played an important role in El Palmar's political organisation during the Late Classic period (c. AD 600800). During two field seasons (2010-2012), excavations uncovered structures GZ1 and GZ6, which border the east and north sides of the plaza respectively. The stair blocks of structure GZ1 were well preserved, despite limited damage caused by modern human activities and natural processes. The stairway connects to a vaulted chamber containing two $0.4 \mathrm{~m}$-high benches at its north and south ends. Epigraphic studies indicate that the completion ceremony of the hieroglyphic stairway took place on 13 September AD 726 (or 9.14.15.0.0) (Tsukamoto \& Esparza Olguín 2015). The protagonist in the inscriptions was not an El Palmar ruler, but an official whose name was Ajpach' Waal. He claims to 


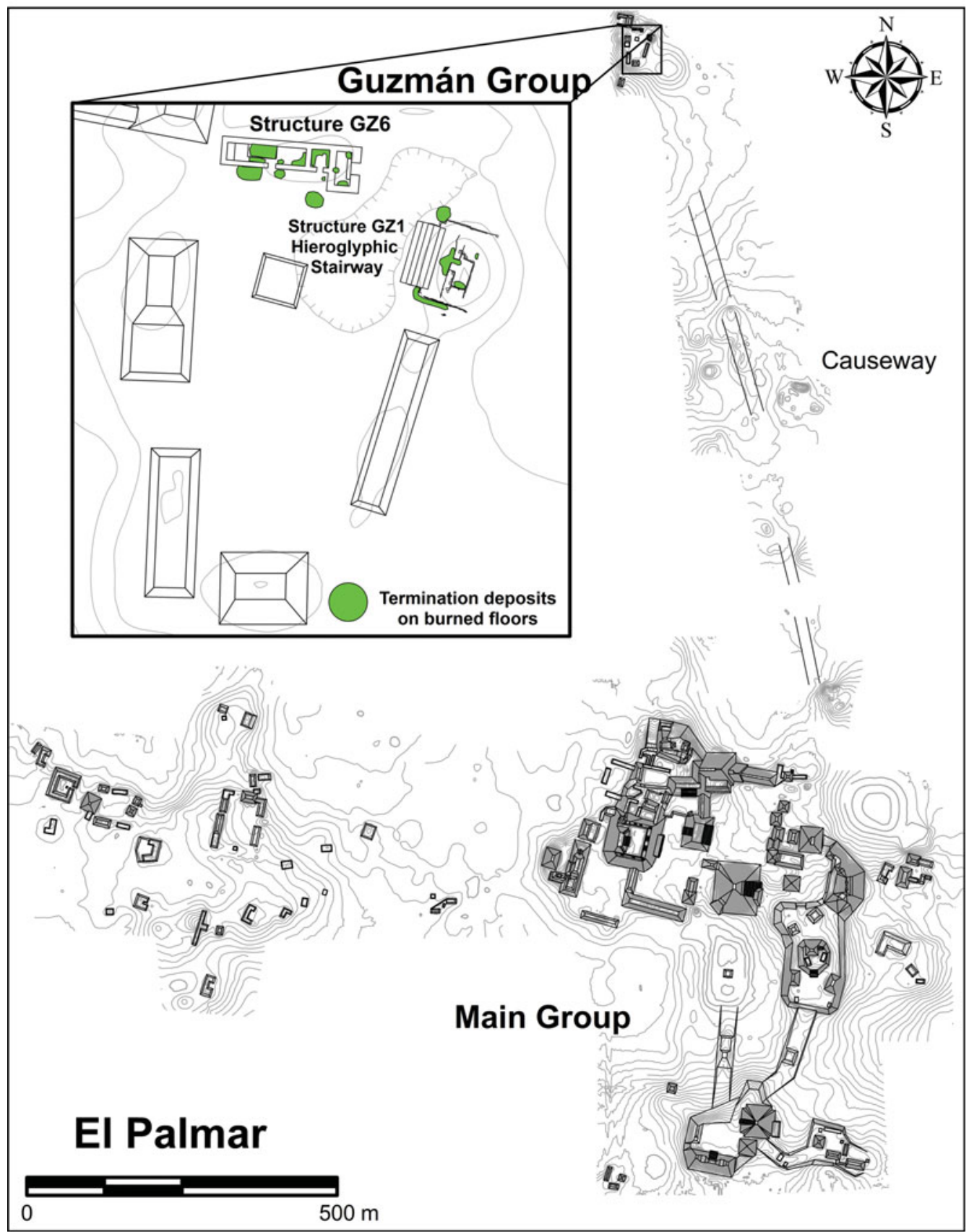

Figure 2. Map of El Palmar showing the location of the Main Group and the Guzmán Group.

(C) Antiquity Publications Ltd, 2017 
be a descendant of a social segment that held the title lakam (meaning 'banner' in the Yukatek Mayan language), running back at least to his great-grandfather. The ancient Maya often claimed land ownership by em-

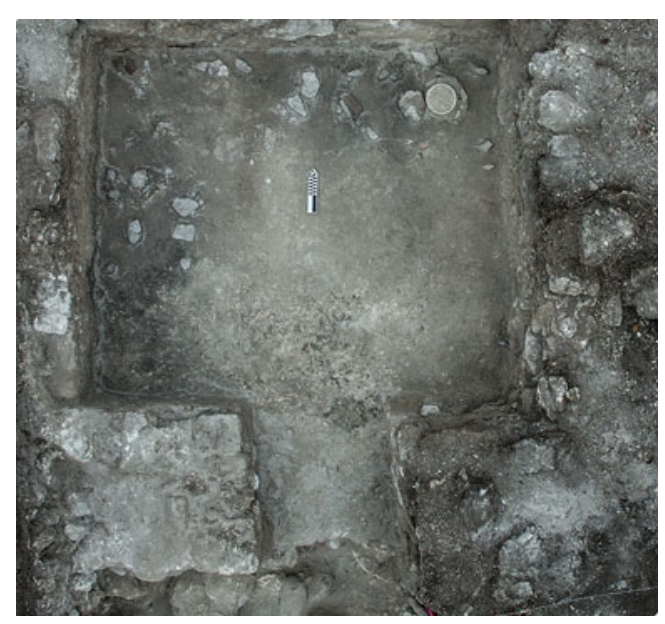

Figure 3. Termination deposits in the central room of structure GZ6. phasising genealogical ties to ancestors (McAnany 1995). In fact, our excavations below the floor of structure GZ1 revealed a human burial contemporaneous with the building of the hieroglyphic stairway (Tsukamoto et al. 2015). Moreover, the inscriptions carved on step IV of the stairway state that the temple (GZ1) was owned by Ajpach' Waal (Tsukamoto \& Esparza Olguín 2015: 44-45). This evidence suggests that the lakam officials occupied the Guzmán Group over generations, although this interpretation needs to be confirmed by further research. Around this time, the lakam officials constructed a plaza to accommodate a large audience, extending the tread width of each step in the stairway to create a stage for theatrical performance (Tsukamoto 2014: 62-63, fig. 3.3).

Structure GZ6 is a rectangular building divided into three vaulted rooms. The west room is the largest space, with the central and lateral masonry benches placed at its centre and the west end. The central room is a tiny quadrangular space $(2.1 \times 2.1 \mathrm{~m})$ that was presumably used for storage. The west and central rooms have independent entrances facing the plaza. In contrast, the east room appears to have been associated with different activities as its entrance points to the east, rather than to the plaza. Our excavations yielded considerable quantities of artefacts from the floor surfaces of both structures (GZ1 and GZ6), sealed by collapsed vault stones.

\section{Termination ritual at the Guzmán Group}

The Guzmán Group was abandoned with a termination ritual, wherein broken artefacts were placed on the floor surfaces in and around structures, which were then burned. We identified ritual deposits both inside structure GZ1 and along its northern and southern outer walls, and inside the rooms and south entrance of structure GZ6. Radiocarbon dating suggests that the site was abandoned with the termination ritual in the period between AD 760 and 980, although this date requires refinement (Tsukamoto et al. 2015: 208, tab. 1).

A variety of artefacts were left on the burnt floors of structures GZ1 and GZ6 (Figure 3). The deposits contained fragmentary serving and cooking vessels, obsidian prismatic blades, chert lithic artefacts, greenstone celts, an incense bowl, grinding stones or manos, shells and human and faunal bones (Table 1). Two chert bifaces were also recovered lying on the hieroglyphic stairway and a broken tripod plate on its platform (Figure 4). 
Table 1. List of termination deposits at structures GZ1 and GZ6 of the Guzmán Group.

\begin{tabular}{|c|c|c|c|c|c|c|c|c|c|}
\hline Ceramic type & GZ1 & GZ6 & Subtotal & $\%$ & Other materials & GZ1 & GZ6 & Subtotal & $\%$ \\
\hline Monochrome sherd & 573 & 323 & 896 & 35.14 & Obsidian prismatic blade & - & 9 & 9 & N/A \\
\hline Bichrome sherd & 18 & 55 & 73 & 2.86 & Greenstone celt & - & 2 & 2 & N/A \\
\hline Polychrome sherd & 8 & 20 & 28 & 1.1 & Groundstone sphere & - & 1 & 1 & N/A \\
\hline Unslipped sherd & 790 & 462 & 1252 & 49.1 & Mano & - & 2 & 2 & $\mathrm{~N} / \mathrm{A}$ \\
\hline Thin Orange sherd & - & 2 & 2 & 0.08 & Shell & - & 3 & 3 & N/A \\
\hline $\begin{array}{l}\text { Eroded or } \\
\quad \text { unidentified sherd }\end{array}$ & 77 & 222 & 299 & 11.73 & Animal bone & 1 & - & 1 & N/A \\
\hline Total & 1466 & 1084 & 2550 & 100 & Human bone & 1 & - & 1 & N/A \\
\hline Chert lithic & GZ1 & GZ6 & Subtotal & $\%$ & & & & & \\
\hline Biface & 10 & 12 & 22 & 12.36 & & & & & \\
\hline Chisel & 1 & 1 & 2 & 1.12 & & & & & \\
\hline Core & - & 11 & 11 & 6.18 & & & & & \\
\hline Domed smoother & 1 & - & 1 & 0.56 & & & & & \\
\hline Eccentric & - & 1 & 1 & 0.56 & & & & & \\
\hline Pick & 1 & - & 1 & 0.56 & & & & & \\
\hline Pounder & - & 8 & 8 & 4.49 & & & & & \\
\hline Projectile point & 1 & - & 1 & 0.56 & & & & & \\
\hline Scraper & 2 & 1 & 3 & 1.69 & & & & & \\
\hline Decortication flake & 7 & 54 & 61 & 34.27 & & & & & \\
\hline Flake with use-wear & 15 & 29 & 44 & 24.72 & & & & & \\
\hline $\begin{array}{l}\text { Flake without } \\
\text { use-wear }\end{array}$ & 10 & 13 & 23 & 12.92 & & & & & \\
\hline Total & 48 & 130 & 178 & 100 & & & & & \\
\hline
\end{tabular}

Inside the chamber of structure GZ1, the artefacts were located along the internal walls. Ethnoarchaeological studies have shown that this spatial pattern of artefact distribution represents refuse disposal (Deal 1985: 254), but it is posited here that the assemblages in structure GZ1 are termination deposits, due to the reassembling patterns described below.

\section{Spatial analyses of termination deposits}

Before reassembling sherds, the spatial patterns of floor assemblages in and around structures GZ1 and GZ6 were analysed. During fieldwork, we documented the location of each artefact with two total stations, with the exception of materials deposited along the north and south walls of structure GZ1. Due to time restrictions, we collected the material deposits in these excavation units using a $2 \times 2 \mathrm{~m}$ grid. In the laboratory, we classified all of the artefacts based on typology and other modal attributes, including form. The results show different distributional patterns between the inside and outside of the rooms, and between structures GZ1 and GZ6. Structure GZ1 had material concentrations inside the temple and in front of its doorway (Figure 5). Artefacts inside the temple were exclusively ceramic bowls and jars, although some sherds were too fragmentary to allow identification of their form. The platform surface in front of the entrance held several artefacts, including the tripod plate mentioned above, and bowls, jars, a broken biface and unidentified sherds.

(C) Antiquity Publications Ltd, 2017 

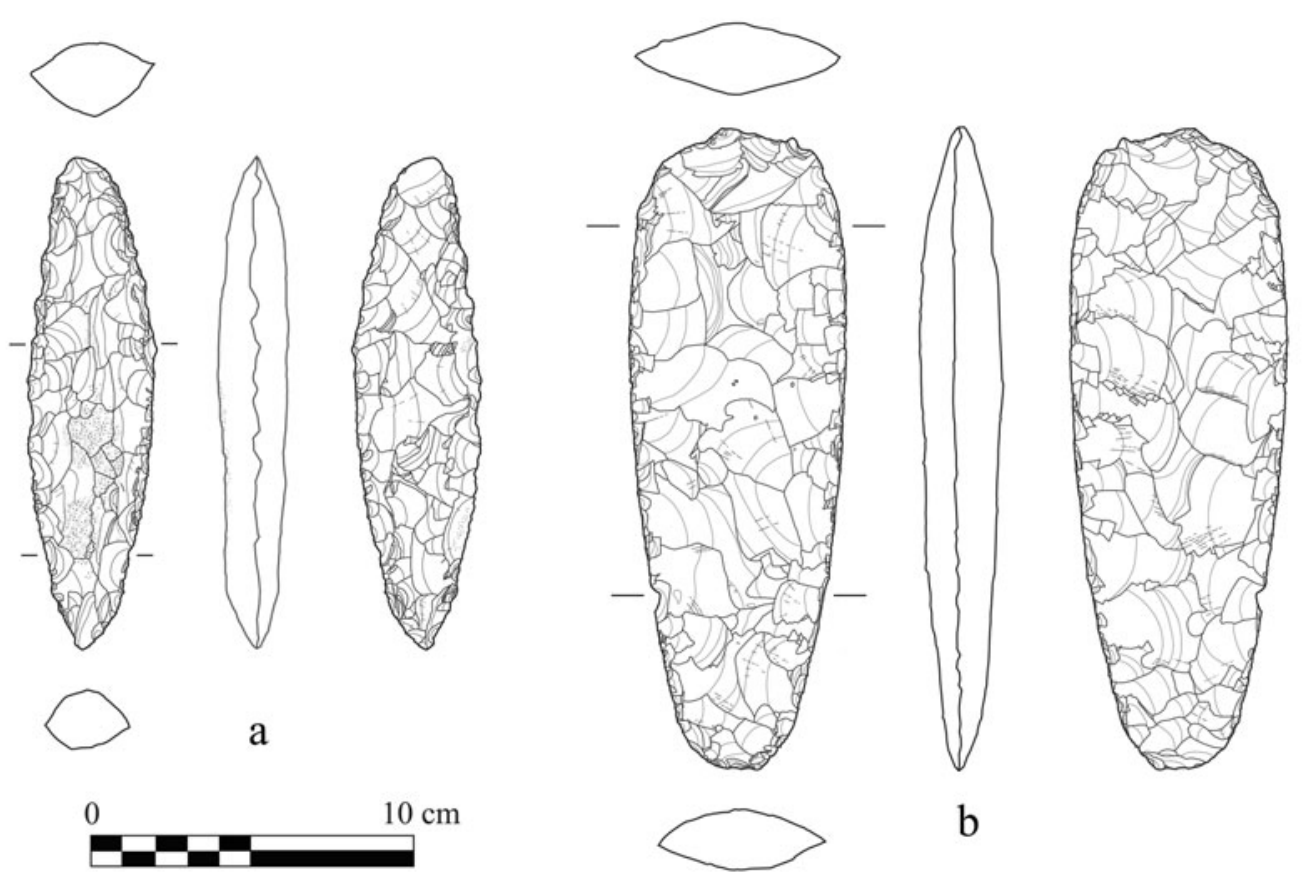

Figure 4. Chert bifaces found on the hieroglyphic stairway of structure GZ1 (for their locations, see Figure 5).

The termination deposits at structure GZ6 represent distinct spatial patterns. Figure 6 shows that most of the bowls and dishes were associated with the west room, whereas plates were located in the central and east rooms. No apparent pattern in the distribution of jar fragments was identified, although this form represented a crucial spatial pattern, once reassembled, that will be discussed later in the paper. On the lateral bench, we found only a tiny, complete incense bowl and a groundstone sphere. In structure GZ6, numerous lithic artefacts were located on the central bench of the west room and on the plaza space in front of the south wall, while a few lithic materials were found in the central and east rooms (Figure 7). The east room also held a complete greenstone celt in a niche-like space. A cache on the plaza surface, containing a chert eccentric, a mano, an obsidian prismatic blade and shells, was recovered from in front of the south wall (Tsukamoto et al. 2015: 210, fig. 9). The cache indicates that this plaza was a critical space for ritual participants.

Do these results so far demonstrate that the ancient Maya intentionally placed specific vessels in specific places? Other than the cache, it is hard to determine if the placement of different types and forms was deliberate or accidental. To resolve this question further, sherds were reassembled in the laboratory. We began by reassembling sherds from a single excavation unit, then from among the different units associated with each structure, and finally from all structures taken together. When two sherds were reassembled, a line was drawn between their find locations on a map, to indicate that they were originally from the same vessel (Figure 8). 


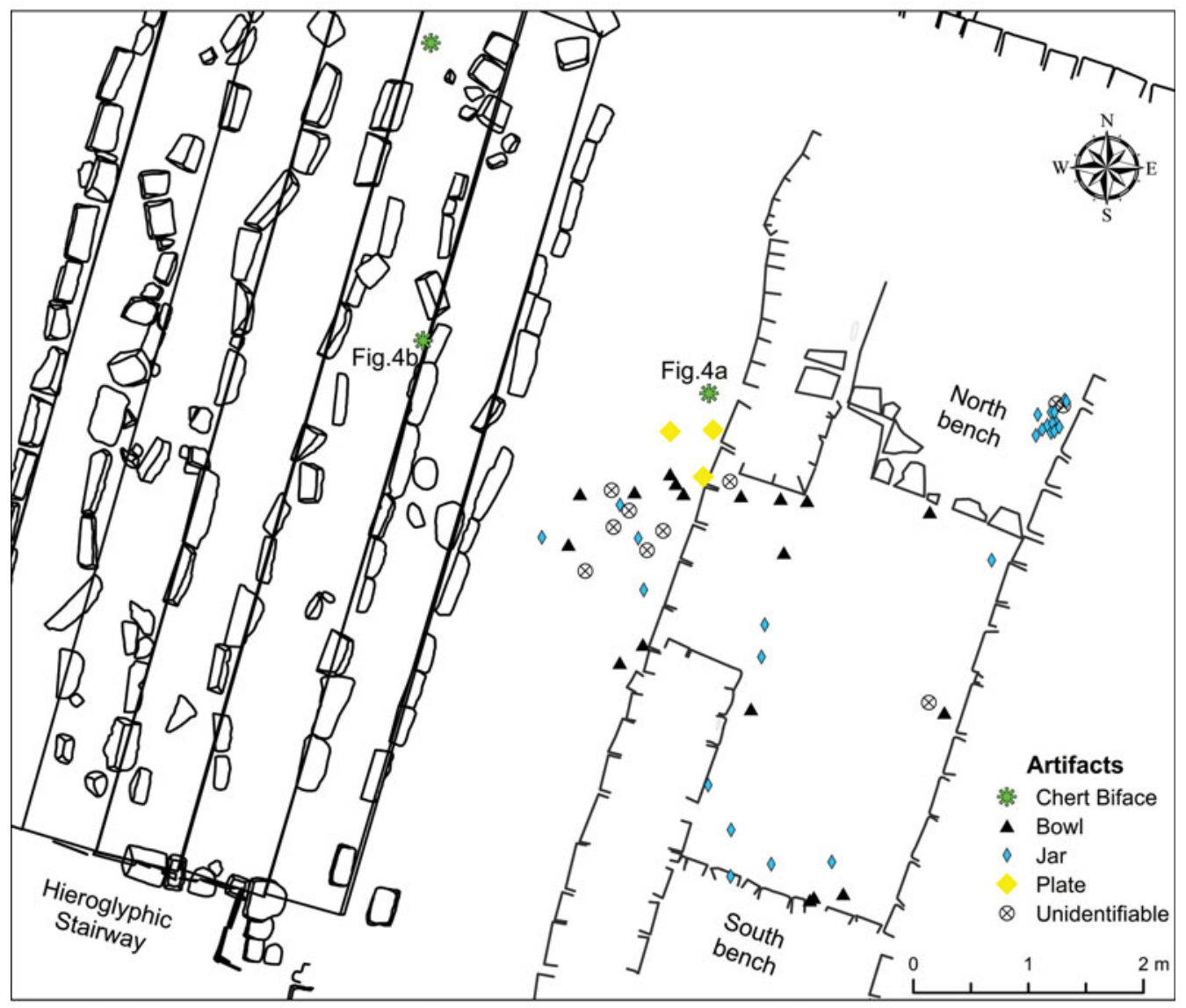

Figure 5. The spatial distribution of termination deposits in structure GZ1.

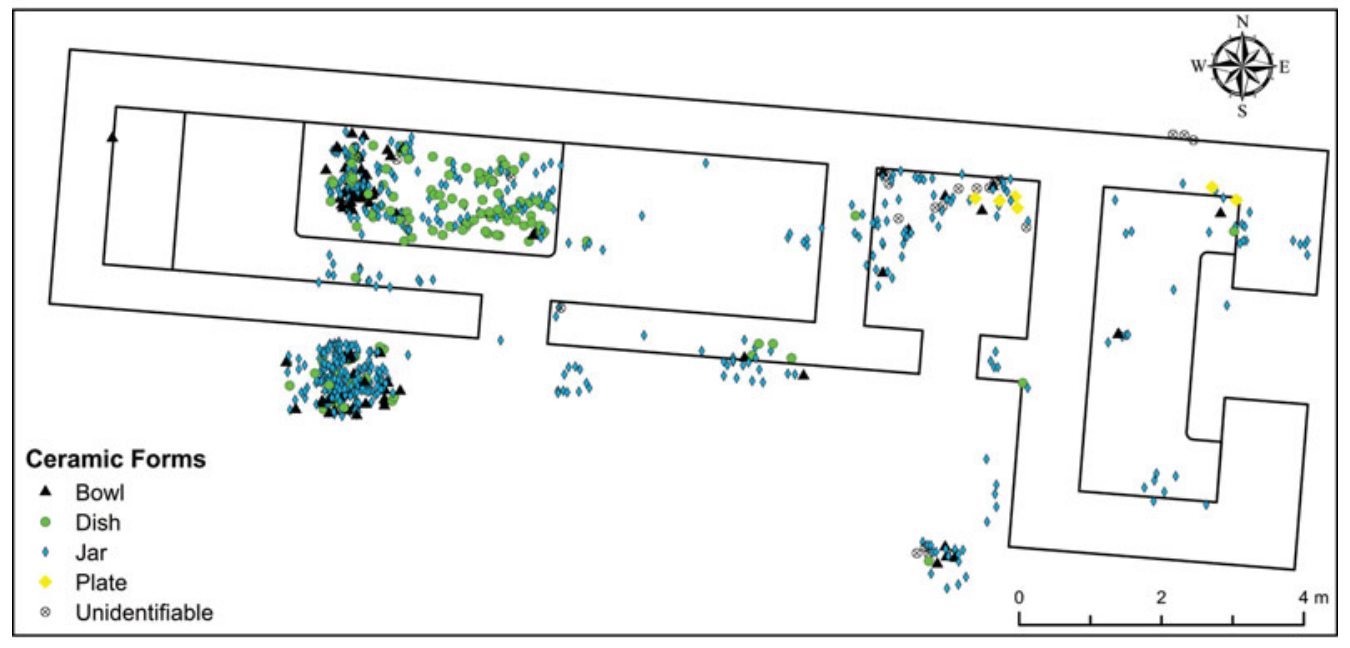

Figure 6. The spatial distribution of ceramic fragments in structure GZ6.

(C) Antiquity Publications Ltd, 2017 


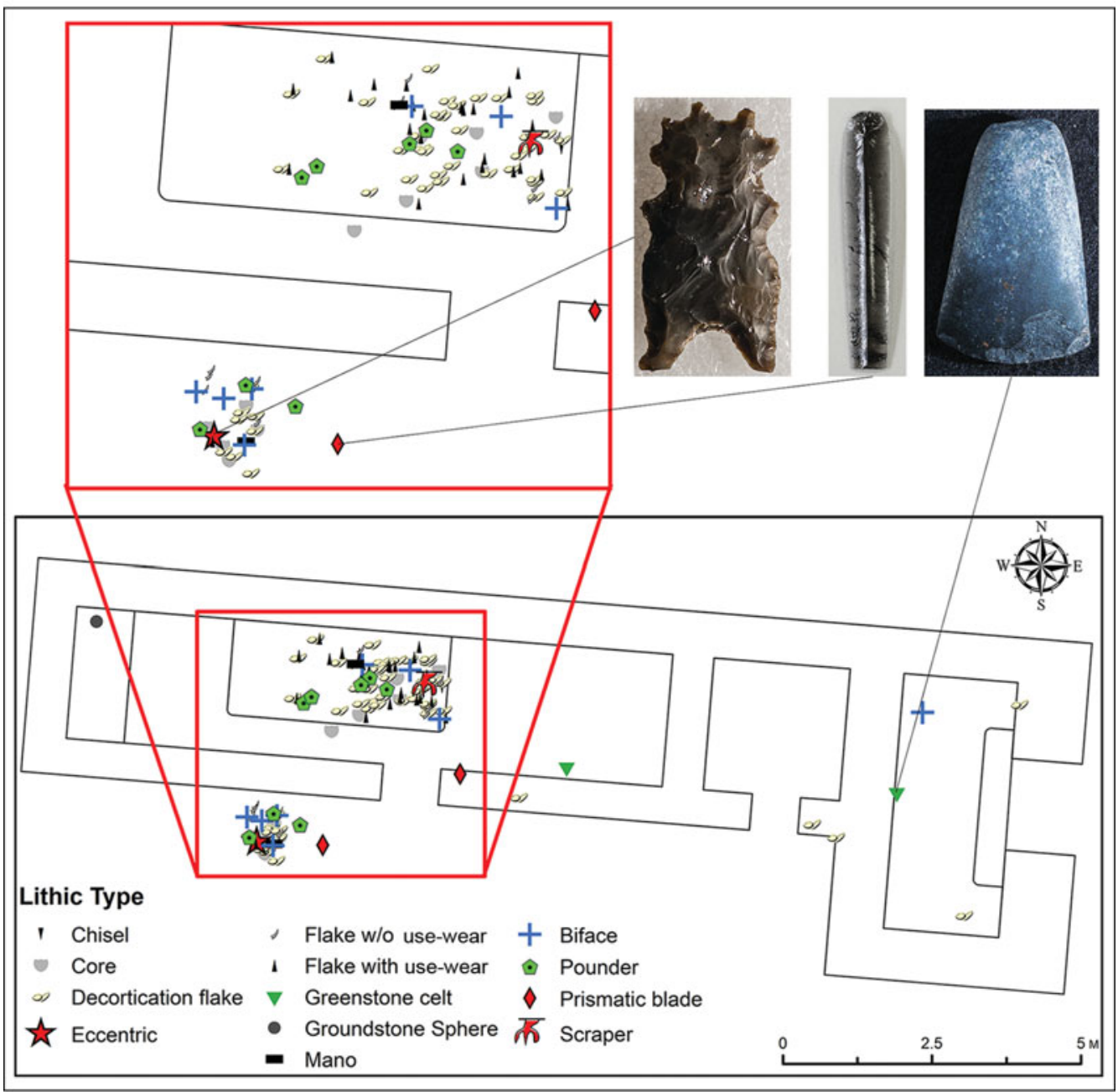

Figure 7. The spatial distribution of lithic artefacts in structure GZ6.

The results show that ritual participants used at least 201 vessels for a termination event in the excavated areas (Table 2). At structure GZ1, they placed at least 75 vessels, some of the fragments of which were found in and around the temple. Some sherds from inside and outside the temple were reassembled, indicating that those along the base of the interior walls are associated not with a discard context, as ethnoarchaeological studies had suggested, but with the termination ritual. At structure GZ6, at least 126 vessels were smashed. Some of these were then scattered into the three rooms, and others on the plaza surface along the south wall. A line connecting two sherds between rooms inside structures GZ1 and GZ6 is crucial, as this evidence confirms that the termination rituals at both structures were contemporaneous. Although complete vessels could not be reconstructed, these results suggest the possibility of achieving this, had the entire group been excavated. 


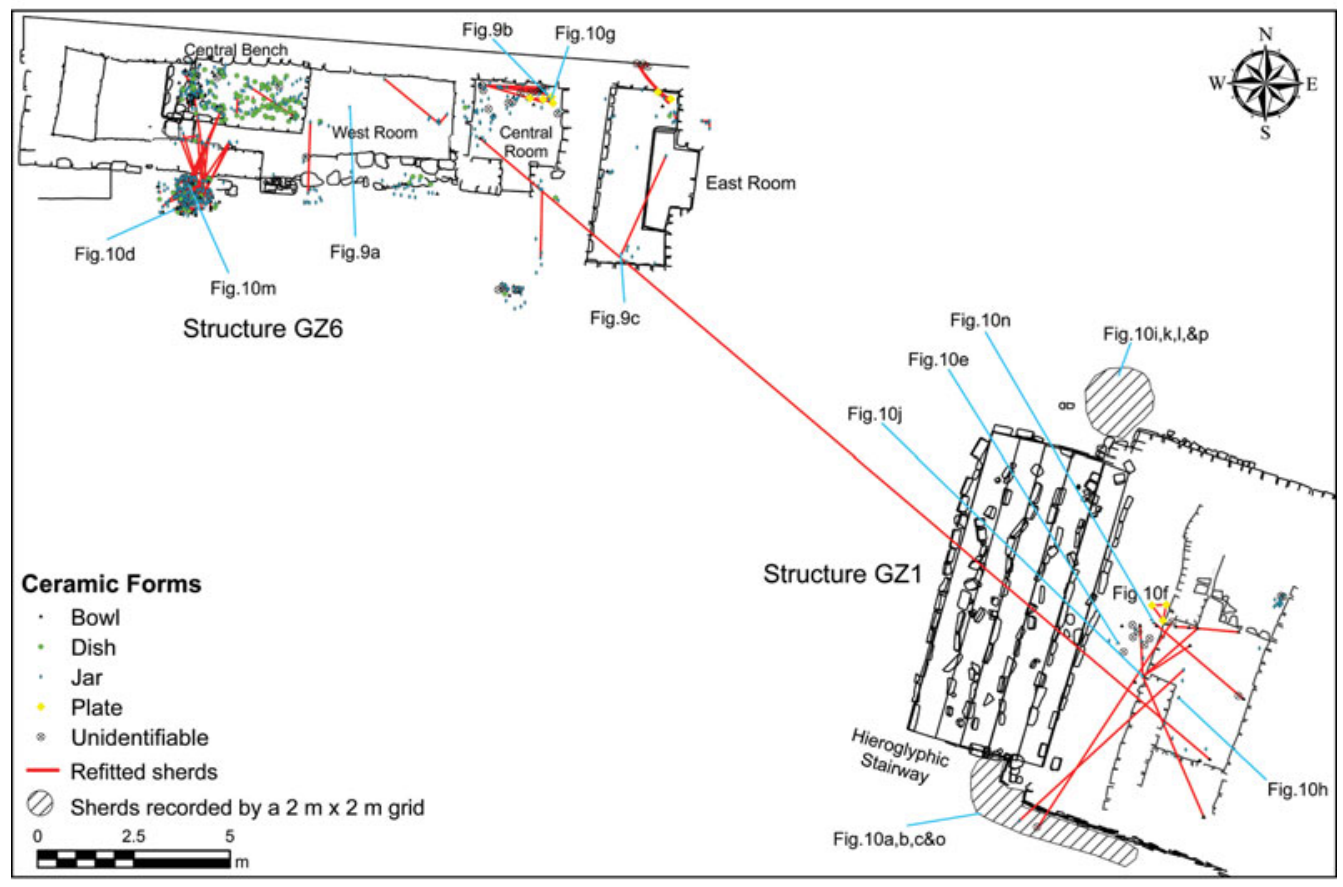

Figure 8. Distribution of artefacts in termination deposits. Red lines illustrate reassembled sherds.

Table 2. Minimum number of vessels recovered from structures GZ1 and GZ6 of the Guzmán Group.

\begin{tabular}{lccc}
\hline Ceramic form & GZ1 & GZ6 & Subtotal \\
\hline & & & \\
Apron lid & - & 1 & 1 \\
Basin & - & 2 & 2 \\
Bowl & 34 & 23 & 57 \\
Dish & 9 & 44 & 53 \\
Incense bowl & - & 1 & 1 \\
Jar & 22 & 46 & 68 \\
Plate & 5 & 1 & 7 \\
Tecomate & - & 1 & 1 \\
Vase & - & 5 & 1 \\
Unidentifiable & 5 & $\mathbf{1 2 6}$ & 10 \\
Total & $\mathbf{7 5}$ & & $\mathbf{2 0 1}$ \\
\hline
\end{tabular}

As mentioned above, the spatial distribution of jar sherds before reassembly did not present any significant pattern. Nevertheless, we reconstructed the upper halves of three jars (Figure 9), the fragments of which had been found in three separate rooms-the west, central and east rooms of structure GZ6 (see Ramírez Hernández 2015). This may imply that ritual participants intentionally placed each jar on the floor of each room. It is unlikely that scattered sherds coincidently form the upper half of the jar in the room without finding any sherd of the lower part. The pattern further suggests that the jars were (C) Antiquity Publications Ltd, 2017 


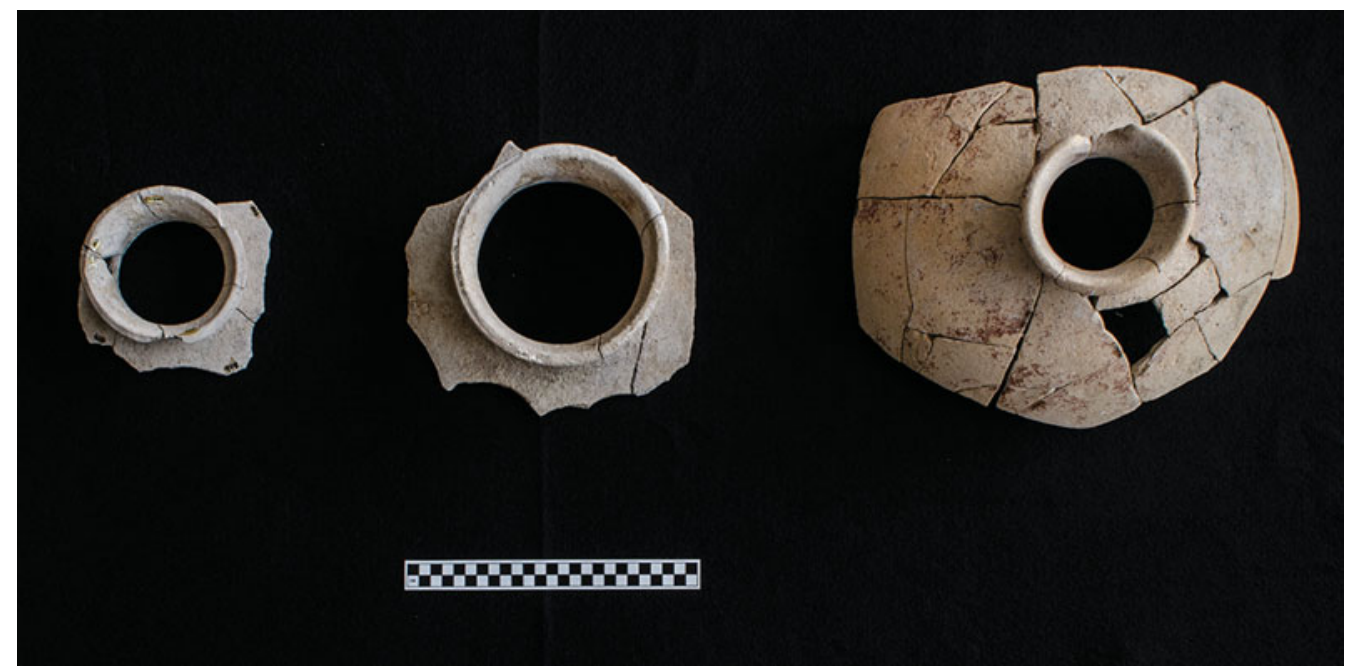

Figure 9. Smashed jars found in the rooms of structure GZ6. The jars from left to right were located in the west, central and east rooms respectively (for their locations, see Figure 8).

smashed elsewhere, after which the upper halves were brought to each room. It is, therefore, concluded that the sherds were not randomly scattered.

\section{Reconstructing feasts through termination deposits}

Measuring the diameters of ceramic vessels in archaeological and ethnoarchaeological research has revealed the socio-political implication of feasting and feasts in ancient communities. These studies have shown that large vessels over $0.3 \mathrm{~m}$ in diameter were used for feasting (Nelson 1991; Pauketat \& Emerson 1991; Crown 1994; Spielmann 1998; Mills 2007). A problem with the archaeological study of feasting is that excavations rarely yield complete vessels. Reassembling sherds is one way to mitigate this (Rosenswig 2007), although it is recognised that results based on incomplete vessels are an approximation. A common problem in this procedure arises from asymmetry (Rice 1987: 223), and estimating maximum diameter from the sherds is not the best proxy measure of overall vessel size (Mills 1999: 106). Data gathered by this method may not reflect subtle changes (less than $20 \mathrm{~mm}$ ) in rim diameter. It is, however, argued here that they still provide a useful parameter for assessing the relationship between serving vessels and feasting in a given context. During our experiments with a whole vessel, error significantly increased when drawing with under 5 per cent of the total circumference present (see also Rosenswig 2007: 13). For reliable results, we selected rim sherds with more than 10 per cent of the total circumference. Serving vessels at El Palmar tended to have relatively symmetrical shapes. Thus, error ranges between 5 and $20 \mathrm{~mm}$ do not significantly affect the identification of a tendency towards overall vessel sizes deposited in the termination ritual. Plates, dishes and bowls were selected to assess the evidence of feasting at the Guzmán Group. Jars were excluded from the analysis of feasting because large jars were often used for storage and the rim diameter does not represent the actual vessel size. 
Table 3. The diameter of refitted sherds.

\begin{tabular}{lccc}
\hline & GZ1 & GZ6 & Subtotal \\
\hline & & & \\
$<0.3 \mathrm{~m}$ & 23 & 2 & 25 \\
$\geq 0.3 \mathrm{~m}$ & 22 & 6 & 28 \\
Total & $\mathbf{4 5}$ & $\mathbf{8}$ & $\mathbf{5 3}$ \\
\hline
\end{tabular}
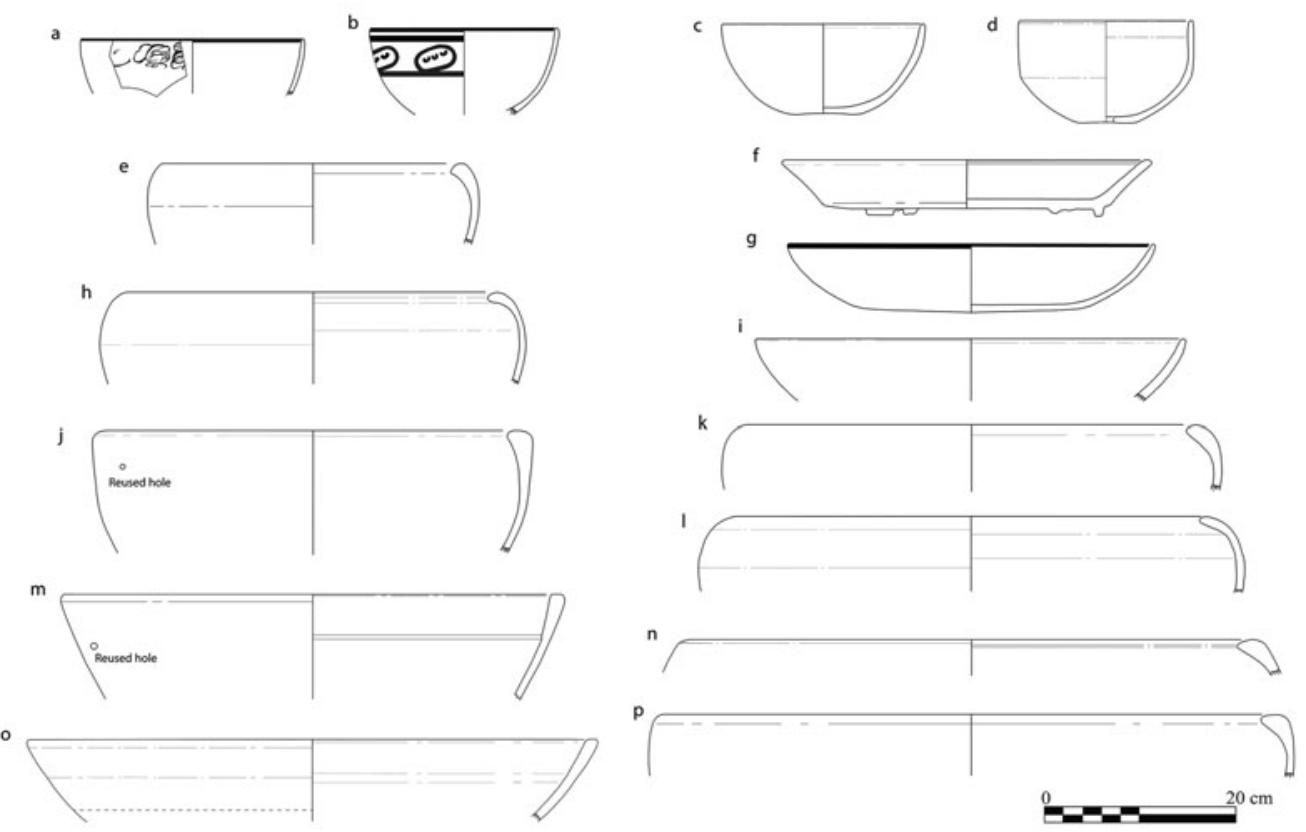

Figure 10. Serving vessels found in termination deposits (for their locations, see Figure 8).

The results from measuring vessel diameters suggest that people organised feasts in the plaza of the Guzmán Group. In the termination deposits, 53 per cent of the plates, dishes and bowls identified $(\mathrm{N}=28 / 53)$ exceeded $0.3 \mathrm{~m}$ in maximum diameter (Table 3$)$. The deposits included three plates over $0.35 \mathrm{~m}$ in diameter (Figure $8 \mathrm{f}, \mathrm{g} \& \mathrm{i}$ ), a $0.58 \mathrm{~m}$-diameter dish (Figure 8o) and two bowls over $0.6 \mathrm{~m}$ in diameter (Figure $8 \mathrm{n} \& \mathrm{p}$ ). The presence of these vessels may indicate that some of the ceramic assemblages in the termination deposits were used for public gatherings. Many of the large vessels had heavy use-wear and evidence of reuse (Figure 10j \& $\mathrm{m}$ ), suggesting that they were in constant use over a long period prior to the site's abandonment.

\section{Discussion}

Who conducted the termination ritual? It is suggested here that external enemies or internal antagonistic factions were not responsible for the termination activities at the Guzmán (C) Antiquity Publications Ltd, 2017 
Group, although the possibility cannot be discounted. Instead, the lakam officials, or at least the inhabitants who occupied the Guzmán Group, could have terminated structures GZ1 and GZ6 for the following reasons. First, when enemies terminated structures at other Maya centres, they often dismantled stairways (e.g. Inomata et al. 2001; Martin \& Grube 2008: 73; Helmke \& Awe 2016). The hieroglyphic stairway at the Guzmán Group was in a good state of preservation. If the ritual participants had been enemies or internal antagonistic factions, they would have most probably targeted the hieroglyphic stairway - the most ideologically significant monument at the Guzmán Group. Researchers may suggest that the chert bifaces on the stairway are evidence of violent conflict, yet polychrome vessels often depict the Maya holding long spears with chert bifaces during rituals (Kerr 1998). Secondly, ritual practitioners carefully deposited a cache together with broken artefacts outside the west room of structure GZ6. If attackers had wanted to humiliate the lakam officials, they would not have deposited these precious goods so prudently. Elsewhere we interpreted that a greenstone celt found in the east room of structure GZ6 may not be associated with the termination deposits (Tsukamoto et al. 2015: 210); reassembly of the upper halves of the three jars described above suggests, however, that the celt could also have been part of the termination ritual. These multiple lines of evidence, therefore, may indicate that the lakam officials performed the ritual. If this interpretation is correct, the event was a reverential, rather than desecratory, termination ritual.

The spatial distribution of floor assemblages highlights not only the behavioural aspects of the termination ritual, but also emic perspectives on space. The placement of the three top-half jars and the cache at structure GZ6 strongly suggests that the lakam officials did not randomly place artefacts. If that is the case, they may also have placed other artefacts intentionally. The spatial pattern of bowls and dishes inside structures GZ1 and GZ6 supports this hypothesis, although the meaning has yet to be fully explored. In contrast to a few materials on the lateral bench, a large number of artefacts recorded on the central bench of structure GZ6 accentuate its significance in the structure. In ancient Maya society, the central masonry bench in a structure symbolised political authority (Harrison 2001), and the height of the central bench $(0.7 \mathrm{~m})$ at structure GZ6 attests to this (Tsukamoto et al. 2015: 208). This height is notable when comparing it to the lateral bench, which is only $0.2 \mathrm{~m}$ high. The different heights suggest that the central bench of structure GZ6 was designed for reception and meeting, while the lateral bench was for private activities and/or sleeping. The small incense bowl recovered from the lateral bench may attest to this. The central bench is, in fact, visible from the plaza. Thus, the termination ritual highlighted the political implication of the stone benches.

Feasting provides social cohesion and power negotiation. During ritual events in the plaza, feasting often became a central practice that allowed social actors to reify their generosity and economic wealth, through which invisible social distance and hierarchy were enhanced (Dietler \& Hayden 2001). Ritual hosts sponsored feasts where they provided lavish meals served on large and luxurious vessels. Prestige vessels used for feasts with precious foods and drinks were an effective means of representing social status and the significance of ritual events in a community. Did people organise a feast during the 
termination ritual at the Guzmán Group? While the presence of large vessels in the termination deposits may suggest a feast in the abandonment process, only a single animal bone recovered from the deposits weakly supports this notion. Heavy use-wear traced on large vessels suggests that the lakam officials organised feasts several times after the creation of the plaza space. Together with the building of a hieroglyphic stairway, these events could have highlighted the officials' socio-political status. It is suggested here that the Guzmán plaza was designed as a political arena in which lakam officials conducted theatrical performances on the hieroglyphic stairway, providing ritual participants with large meals and drinks.

\section{Conclusion}

This study has assessed the importance of spatial analyses, based on quantitative data, that allow the identification of abandonment processes in detail. In ancient Maya society, site abandonment often entailed termination rituals that varied according to political circumstances and historical contingencies. Material remains and their spatial distributions at the Guzmán Group of El Palmar were confusing, as chert bifaces have often been identified as evidence for desecratory termination rituals, while artefacts located against internal walls have been identified as domestic refuse. Nevertheless, multiple lines of evidence suggest that the termination ritual detected at the Guzmán Group was reverential. While the available data cannot determine whether a feast was held during the termination ritual, the presence of large vessels with heavy use-wear indicates the socio-political significance of feasting in the Guzmán plaza. Future excavations at other structures of the Guzmán Group will address this question.

As previously mentioned, long-standing archaeological research has revealed a wide array of termination rituals and abandonment processes in Classic Maya society. There may still be unidentified processes waiting for illumination through archaeological research. A lesson from the El Palmar case presented here is that we should not automatically identify past events through a few diagnostic artefacts. Comprehensive contextual analyses with sophisticated theoretical and methodological approaches provide a greater understanding of the spatial dynamics inherent in the abandonment processes of early complex societies.

\section{Acknowledgements}

I would like to express my sincere gratitude to peer reviewers Stephen Houston and David Freidel, who provided thoughtful comments and helpful suggestions. I am also grateful to Marijke Stoll who helped improve the early draft of this manuscript. I extend my gratitude to Javier López Camacho, Hirokazu Kotegawa, Araceli Vázquez Villegas, Aban Flores Morán, Mariana Favlia Vázquez and Dulce María Ramírez Hernández for assistance in material analyses and drawing. Archaeological research at El Palmar was generously permitted by the Consejo de Arqueología of the Instituto Nacional de Antropología e Historia. I thank the University of California, Riverside, Aoyama Gakuin University, the Escuela Nacional de Antropología e Historia and the Centro INAH Campeche for their support. Fieldwork at the Guzmán Group of El Palmar was funded by the National Science Foundation (BCS-11640); the Japan Society for the Promotion of Science Postdoctoral Research Fellowship (15J00280); KAKENHI (21402008) awarded by Kazuo Aoyama; the National Geographic Society;

(C) Antiquity Publications Ltd, 2017 


\section{Reverential abandonment}

Konosuke Matsushita Memorial Foundation; and the Lewis and Clark Fund of the American Philosophical Society.

\section{References}

Agurcia, R.F. \& B.W. Fash. 2005. The evolution of structure 10L-16, heart of the Copán acropolis, in E.W. Andrews \& W.L. Fash (ed.) Copañ: the history of an ancient Maya kingdom: 201-37. Santa Fe (NM): School of American Research; Oxford: James Currey.

Coe, W.R. 1959. Piedras Negras archaeology: artifacts, caches, and burials. Philadelphia: The University Museum, University of Pennsylvania.

Crown, P.L. 1994. Ceramics and ideology: Salado polychrome pottery. Albuquerque: University of New Mexico Press.

Deal, M. 1985. Household pottery disposal in the Maya highlands: an ethnoarchaeological interpretation. Journal of Anthropological Archaeology 4: 243-91. https://doi.org/10.1016/0278-4165(85)90008-X

Dietler, M. \& B. Hayden. 2001. Digesting the feast-good to eat, good to drink, good to think: an introduction, in M. Dietler \& B. Hayden (ed.) Feasts: archaeological and ethnographic perspectives on food, politics, and power: 1-20. Washington, D.C.: Smithsonian Institution.

Freidel, D.A. 1986. The monumental architecture, in R.A. Robertson \& D.A. Freidel (ed.) Archaeology at Cerros, Belize, Central America, volume 1, an interim report: 1-22. Dallas (TX): Southern Mesodist University Press.

Freidel, D.A. \& L. Schele. 1989. Dead kings and living temples: dedication and termination rituals among the ancient Maya, in W.F. Hanks \& D.S. Rice (ed.) Word and image in Maya culture: explorations in language, writing, and representation: 233-43. Salt Lake City: University of Utah Press.

Garber, J.F. 1989. Archaeology at Cerros Belize, Central America, volume II, the artifacts. Dallas (TX): Southern Methodist University Press.

Grove, D. 1984. Chalcatzingo, excavations on the Olmec frontier. New York: Thames \& Hudson.

HaRrison, P.D. 2001. Thrones and throne structures in the central acropolis of Tikal as an expression of the royal court, in T. Inomata \& S.D. Houston (ed.) Royal courts of the ancient Maya, volume one: theory, comparison, and synthesis: 74-101. Boulder (CO): Westview.

Helmke, C. \& J.J. Awe. 2016. Death becomes her: an analysis of panel 3, Xunantunich, Belize. The PARI Journal XVI: 1-14.
Hutson, S.R., T.W. Stanton, A. Magnoni, R. Terry \& J. Craner. 2007. Beyond the buildings: formation processes of ancient Maya houselots and methods for the study of non-architectural space. Journal of Anthropological Archaeology 26: 442-73. https://doi.org/10.1016/j.jaa.2006.12.001

INOMATA, T. 2003. War, destruction, and abandonment: the fall of the Classic Maya center of Aguateca, Guatemala, in T. Inomata \& R.W. Webb (ed.) Archaeology of settlement abandonment in Middle America: 43-60. Salt Lake City: University of Utah Press.

Inomata, T., D. Triadan, E. Ponciano, R. Terry \& H.F. Beaubien. 2001. In the palace of the fallen king: the royal residential complex at Aguateca, Guatemala. Journal of Field Archaeology 28: 287-306. https://doi.org/10.1179/jfa.2001.28.3-4.287

KerR, J. 1998. The Maya vase book: a corpus of rollout photographs of Maya vases. New York: Associates.

LaMotta, V.M. \& M.B. Schiffer. 1999. Formation processes of house floor assemblages, in P.M. Allison (ed.) The archaeology of household activities: 19-29. Oxford: Routledge.

Lamoureux-St-Hilaire, M., S. Macrae, C.A. McCane, E.A. Parker \& G. Iannone. 2015. The last groups standing: living abandonment at the ancient Maya center of Minanha, Belize. Latin American Antiquity 26: 550-69. https://doi.org/10.7183/1045-6635.26.4.550

Manzanilla, L. 2003. The abandonment of Teotihuacan, in T. Inomata \& R.W. Webb (ed.) The archaeology of settlement abandonment in Middle America: 91-101. Salt Lake City: University of Utah Press.

Martin, S. \& N. Grube. 2008. Chronicle of the Maya kings and queens: deciphering the dynasties of the ancient Maya. London: Thames \& Hudson.

Mатsumoто, Y. 2012. Recognising ritual: the case of Campanayuq Rumi. Antiquity 86: 746-59. https://doi.org/10.1017/S0003598X0004789X

McAnany, P.A. 1995. Living with ancestors: kinship and kingship in ancient Maya society. Austin: University of Texas Press.

Mills, B.J. 1999. Ceramics and the social contexts of food consumption in the northern Southwest, in J.M. Skibo \& G.M. Feinman (ed.) Pottery and people: dynamic interactions: 99-114. Salt Lake City: University of Utah Press.

- 2007. Performing the feast: visual display and suprahousehold commensalism in the Puebloan Southwest. American Antiquity 72: 210-39. https://doi.org/10.2307/40035812

(C) Antiquity Publications Ltd, 2017 
Mock, S.B. (ed.). 1998. The sowing and the dawning: termination, dedication, and transformation in the archaeological and ethnographic record of Mesoamerica. Albuquerque: University of New Mexico Press.

Nelson, B.A. 1991. Ceramic frequency and use-life, in W.A. Longacre (ed.) Ceramic ethnoarchaeology: 162-81. Tucson: University of Arizona Press.

Pagliaro, J.B., J.F. Garber \& T.W. Stanton. 2003. Re-evaluating the archaeological signatures of Maya ritual and conflict, in K.M. Brown \& T.W. Stanton (ed.) Ancient Mesoamerican warfare: 75-89. Walnut Creek (CA): AltaMira.

Pauketat, T.R. \& T.E. Emerson. 1991. The ideology of authority and the power of the pot. American Anthropologist 93: 919-41. https://doi.org/10.1525/aa.1991.93.4.02a00080

Ramírez Hernández, D.M. 2015. Un rito de terminación en el sitio arqueológico El Palmar, Campeche. Unpublished undergraduate dissertation, Universidad Veracruzana.

Rice, P.M. 1987. Pottery analysis: a source book. Chicago (IL): University of Chicago Press.

Robertson, R.A. \& D.A. Freidel (ed.). 1986. Archaeology at Cerros Belize, Central America, volume 1: an interim report. Dallas (TX): Southern Methodist University Press.

Rosenswig, R.M. 2007. Beyond identifying elites: feasting as a means to understand early Middle Formative society on the Pacific Coast of Mexico. Journal of Anthropological Archaeology 26: 1-27. https://doi.org/10.1016/j.jaa.2006.02.002

Spielmann, K.A. 1998. Ritual influences on the development of Rio Grande Glaze A ceramics, in K.A. Spielmann (ed.) Migration and reorganization: the Pueblo IV period in the American Southwest (Arizona State University Anthropological Research Paper 51): 253-61. Tempe: Arizona State University Press.

Stanton, T.W., M.K. Brown \& J.B. Pagliaro. 2008. Garbage of the gods? Squatters, refuse disposal, and termination rituals among the ancient Maya. Latin American Antiquity 19: 227-47. https://doi.org/10.1017/S1045663500007938

STross, B. 1998. Seven ingredients in Mesoamerican ensoulment: dedication and termination in Tenejapa, in S.B. Mock (ed.) The sowing and the dawning: termination, dedication, and transformation in the archaeological and ethnographic record of Mesoamerica: 31-39. Albuquerque: University of New Mexico Press.
Sugiyama, S. 1998. Termination programs and Prehispanic looting at the Feathered Serpent Pyramid in Teotihuacan, Mexico, in S.B. Mock (ed.) The sowing and the dawning: termination, dedication, and transformation in the archaeological and ethnographic record of Mesoamerica: 147-64. Albuquerque: University of New Mexico Press.

Sullivan, L.A., J.B. Hageman, B.A. Houk, P. Hughbanks \& F. Valdez, Jr. 2008. Structure abandonment and landscape transformation: examples from the Three Rivers region, in T.W. Stanton \& A. Magnoni (ed.) Ruins of the past: the use and perception of abandoned structures in the Maya lowlands: 91-111. Boulder: University Press of Colorado.

Tozzer, A.M. 1941. Landa's Relación de las cosas de Yucatán-a translation (Papers of the Peabody Museum of American Archaeology and Ethnology 18). Cambridge (MA): Peabody Museum of American Archaeology and Ethnology.

Tsukamoтo, K. 2014. Multiple identities on the plazas: the Classic Maya center of El Palmar, Mexico, in K. Tsukamoto \& T. Inomata (ed.) Mesoamerican plazas: arenas of community and power: 50-67. Tucson: University of Arizona Press.

Tsukamoto, K. \& O. Esparza Olguín. 2015. Ajpach' Waal: the hieroglyphic stairway at the Guzmán Group of El Palmar, Campeche, Mexico, in C. Golden, S. Houston \& J. Skidmore (ed.) Maya archaeology 3: 30-55. San Francisco (CA): Precolumbia Mesoweb.

Tsukamoto, K., J. López Camacho, L.E. Campaña Valenzuela, H. Kotegawa \& O. Esparza Olguín. 2015. Political interactions among social actors: spatial organization at the Classic Maya polity of El Palmar, Campeche, Mexico. Latin American Antiquity 26: 200-20. https://doi.org/10.7183/1045-6635.26.2.200

Velásquez, J.G. 2015. Dedication and termination rituals in southern Moche public architecture. Latin American Antiquity 26: 87-105. https://doi.org/10.7183/1045-6635.26.1.87

WALKer, D.S. 1998. Smashed pots and shattered dreams: the material evidence for an Early Classic Maya site termination at Cerros, Belize, in S.B. Mock (ed.) The sowing and the dawning: termination, dedication, and transformation in the archaeological and ethnographic record of Mesoamerica: 81-99. Albuquerque: University of New Mexico Press.

WALKER, W.H. 1998. Where are the witches of prehistory? Journal of Archaeological Method and Theory 5: 245-308. https://doi.org/10.1007/BF02428071

Received: 17 September 2016; Accepted: 14 December 2016; Revised: 9 January 2017

(C) Antiquity Publications Ltd, 2017 